\title{
ACADEMIC APPROACH FOR RELIGIOUS RADICALISM
}

\author{
Akhmad Siddiq \\ State Islamic University of Sunan Ampel, Surabaya \\ Email: a.siddiq@uinsby.ac.id
}

\begin{abstract}
Blaming or demonizing other could appear from misunderstanding paradigm toward knowledgeable entities: individually or collectively. Inclusive approach to know and understand other religious groups is a basic principle to build interreligious relation. In his Dialogue Decalogue, Leonard Swidler suggests that to build interfaith dialogue is to learn and understand (other) realities. In this regard, religious radicalism could be perceived as an outcome of misunderstanding that allows people to exclude or ignore others. This paper aims to explore several books of Muslim scholars, both in classical and contemporary period, relating to comparative study of religion. It is the finding of this work that understanding other religions (or religious others) as articulated in the book will create a level of acceptance within religious believers.
\end{abstract}

Keyword: comparative study, interreligious dialogue, radicalism, religion, and Islam.

\section{INTRODUCTION}

I will begin this paper by giving some examples of disappointed feeling for being radical or joining radical community. Through these examples, I want to emphasize that misunderstanding and inappropriate knowledge could drive someone to commit violence and stand with radical movement. First, in the end of 2015 many of Indonesian citizens went to Syria for joining ISIS and living under the Islamic Caliphate. They were informed that the government of ISIS will build a Muslim society based on Sharia where all citizens will be equally recognized and lawfully considered. This year some of them came back to Indonesia, after long journey of horrible adventure with ISIS community, and revealed regret: they have been wrong. They misunderstood ISIS government and knew Islamic radical movement in Syria wrongly (KompasTV, 2017). ${ }^{1}$ They apologized for being trapped in deception and deceitfulness. It was a fundamental mistake because their misunderstanding relates to radical

${ }^{1} \mathrm{http}: / /$ nasional.kompas.com/read/2017/09/15/12500001/wni-eks-simpatisan-isis-saya-khilaf-menyesal 
thought and movement of ISIS.

Second, several months ago, a German young lady, 16 years aged, came with a similar story: she announced her regret joining radical group of ISIS after receiving consular assistance in Iraqi prison. This teenager joined ISIS with three other German girls in recent year, and now-after political and military decline of ISIS-requested to be extradited to her country and aims to cooperate with the authority. ${ }^{2}$ This girl found that everything she had ever dreamed about ISIS was incorrect.

Third, in 2008, one of the Bali bombers (2002), Ali Imron, expressed his regret on exploding tourism area in Denpasar. In his interview, he said that he would always apologize for all the victims, the family, and every person influenced by the explosion. ${ }^{3}$ His repentance related to miscalculation on gigantic effect of the bomb. He persisted that he had reminded his companions to reconsider the effect of Bali bombing. His regret, to some extends, represented unknown space and incomprehensible mind which eventually influenced him to apologize for what he did. In line with Ali Imron, Ali Fauzi (another ex-Bali-bomber) stated his guilt for being involved in Bali bombing. He felt disappointed for being easily recruited and joined radical movement. ${ }^{4}$

The previous examples underline that someone has to know exactly and understand every path of his/her action, especially by which other people can be influenced. Social movement which is rooted on religious purpose will affect social life not only in theological matters, but also cultural, economic, and political. Having a religion means having an understanding of certain faith and recognizing other faiths of different group. In the Qur'an, God explicitly insist that human diversity in term of religious faith has been intentionally designed for human kindness. ${ }^{5}$

In this regard, knowing and understanding-in term of religious studiesare basic principle to construct self-conviction and perceive religious other. Misunderstanding and misperception of other (faith, movement, community, society, state, etc.) would produce prejudice and hatred. In The Dialogue Decalogue: Ground Roles for Interreligious Dialogue (1984), Leonard Swidler insisted that understanding other becomes fundamental element in conducting relational and dialogical process. He wrote that interreligious dialogue is "an attempt to understand the other's position as precisely and, as it were, as

\footnotetext{
${ }^{2}$ https://www.theguardian.com/world/2017/jul/24/home-linda-wenzel-germanteenager-joined-isis-speaks-of-regrets

${ }^{3}$ https://soundbiteasia.wordpress.com/2008/10/13/ali-imron-minta-maaf-bom-bali/

${ }^{4}$ Workshop "Pelatihan Penguatan Perspektif Korban Terorisme di Kalangan Tokoh Agama” held by AIDA (Aliansi Indonesia Damai), Surakarta, March 4-5, 2017.

${ }^{5}$ QS. 10:99 and QS. 16:93.
} 
much from within, as possible." ${ }^{6}$ To strengthen and prove one understands, somebody must confirm his/her understanding by crosschecking it into reality as well as covering both-sided perception.

It is insufficient to embrace only one view and exclude other different views, because-referring to Max Muller-it means nothing. Muller said, "he who knows one, knows none." It is true that to believe is to know and understand, but to believe a religion does not mean to know only one religion. There are hundreds of faiths in the world where each of them has its own uniqueness. When every religion has culturally interconnected for long times before, it is proven that hybridity of religions became a decisive reality. Religious borders represent fluid and progressive entity that should be approached as a research object and method.

In his book, The Christian Muslim Frontier: A Zone of Contact, Conflict or Cooperation, Mario Apostolov (2004) elucidates that religious society is one whole. What influences and creates element of social order is structural division along civilizational frontiers. Apostolov believes that frontiers are specific, binding elements in the institutional network of the world. ${ }^{8}$ To build and shape boundaries between one culture to another is to make blockingstones on connecting a reality with another. It is such an imagination where people tend to separate social spaces based on their political, social, or cultural orientation. Apostolov said, "Any frontier, be it political, social or cultural, is the product of human imagination and an instrument for shaping the structure of human society." Imagination, here, is a space of knowing and understanding. People conceive something based on what they have understood before.

In the process of making religious harmony and avoiding radicalism, it is necessary for religious believer to have comprehensive understanding of religions (plural) and not to support exclusive knowledge of religion (singular). Learning other religions could avoid someone from misunderstanding and misperception on it. Dhun-Nun al-Misrī, a prominent Egyptian scholar, persists that people tend to victimize and demonize what they ignore: al-nās $a^{\prime} d \bar{a} u$ ma jahilū (people are enemies toward everything they did not know). ${ }^{10}$ To respect religious others means to know them rightly and appropriately.

${ }^{6}$ Leonard Swidler, “The Dialogue decalogue: Ground Roles for Interreligious Dialogue", Journal of Inter Religio 5, Spring, 1984, 30-33.

${ }^{7}$ Jacques Waardenburg, Classical Theories of the Study of Religion: Aims, Methods, and Theories of Research (Berlin: de Gruyter, 2017), 90.

${ }^{8}$ Mario Apostolov, The Christian Muslim Frontier: A Zone of Contact, Conflict or Cooperation (New York: Routledge, 2004), 3.

${ }^{9}$ Ibid., 1.

${ }^{10}$ Read Ah\}mad 'Abdul Karīm al-Ghāzī al-'Amirī, Al-Jadd al-Hasis fī Bayāni mā Laisa bi Hadith (Beirut: Dar Ibn H\}azm, 1997), 244. 
In line with this statement, the Quran alerts that people tend to perceive the opposite side of their faith as fairytale (QS. 46:11).

Based on this background, I attempt to explain Muslim opinion concerning other religions, especially in term of comparative study of religion through describing several books written by Muslim scholars, both in classical and contemporary period. Through this paper, I will argue that understanding other faiths is necessary to build respectable relationship and create a level of acceptance within religious believers. ${ }^{11}$ It is worth noting that some radical thoughts and movements toward other religion have been planted among illiterate communities. In this context, it is important to reinvent academic approach for sidestepping radical thought and action.

\section{APOLOGETIC APPROACH AS A DIALOGUE}

In his book, Muslim-Christian Conflict Resolution in Islamic Perspective (published in Bahasa Indonesia, Mengurai Konflik Muslim-Kristen dalam Perspektif Islam), Mahmoud Mustafa Ayoub argued that history of MuslimChristian relationship is in general a story of untrusted-ness, suspicion, and misunderstanding. ${ }^{12}$ Picturing the history of the Crusade, Ayoub pointed three discourses in which Muslim and Christian had been contested for prolonged period: colonialism, evangelism, and orientalism. ${ }^{13}$ These elements represented a melting pot of religious encounter with politics, economy, and power. Ayoub dreamed about harmonious relationship between the two largest religious communities in the world (Muslim and Christian) through sincere dialogue and communication. To reach this purpose, widespread understanding and comprehensive knowledge about religious other are needed.

Exploring modern Muslim scholar's thought, Ayoub mentioned two conventional approaches which have been practiced among Muslim scholar on perceiving Christianity (and other religions): apologetic and polemical. Ayoub took at least four exemplary books of modern Muslim scholar (Muhammad 'Abduh, Rashīd Ridā, Ahmad Shalabī and Abū Zahrah), which discussed Christianity using polemical-apologetic approach. According to Philip Johnson, apologists tend to pursue their doctrinal refutation and alert certain

${ }^{11}$ Read Paul Knitter, Introducing Theologies of Religions (New York: Orbis Books, 2002), 216-224.

${ }^{12}$ Mahmoud Mustafa Ayoub, Mengurai Konflik Muslim-Kristen dalam Perspektif Islam (Yogyakarta: Fajar Pustaka Baru, 2001), 240-241.

${ }^{13}$ Ibid. Read more about this topic in Edward Said, Orientalism (New York: Vintage Book, 1979); Omar Farrukh, Al-Tabshīr wa al-Isti'mār fì al-Bilād al-'Arabiyyah (Globalization and Colonialism in Arab Land) (Beirut: 1982). 
religious believer about the errors of their religions. ${ }^{14}$ This approach reinforces religious believer to perceive and recognize religious others as "infidel". To justify their argumentation, apologists use scriptural texts to claim that their standpoint is authoritatively correct. While Ayoub described the approach within Muslim scholars, Johnson examined it among Christian discourses. In Paul Knitter's term, this position was called "the replacement model", the very basic model among the three others: fulfillment model, mutuality model, and acceptance model. ${ }^{15}$

In the following, I will elucidate several books written by the classical Muslim scholars and other several books written by modern Muslim scholars. These books represent different period of time but following the same approach on writing religious other: polemical-apologetic. However, I will argue later that this approach is part of dialogical relationship between one religious community to another. It is an academic and literary approach by which religious intellectual expressed their peaceful dispute and argument. They prefer to use words than swords on "attacking" religious others.

Let's start with the book of al-Milal wa al-Nihal written by al-Imām Abì alFath Muhammad ibn 'Abdul Karīm al-Shahrastānī (1086-1153). This book has become a magnum opus on comparative study of religions in Islamic tradition. Shahrastānī was a prominent Muslim scholar on Islamic philosophy, theology, and religious study. Among of his books are Nihāyah al-Iqdām fì 'Ilm alKalām, al-Irsyād ilā 'Aqā’id al-'Ibād, Tafsìr Sūrah Yūsufbi Uslūb Falsafī, Talkhīs al-Aqsām li Mazāhib al-Anām, Musāràāt al-Falāsifah, and Mafātih al-Asrār wa Masābih al-Abrār.

Sharastānì divides al-Milal wa al-Nihal into two volumes. The first volume is about believers of faiths and religions (arbāb al-diyānāt wa al-milal) and the second is about the people of thoughts and cults (ahl al-ahwa' wa al-nihal). In the first he classifies three chapters on (1) Muslims, (2) ahl al-kitāb (believer of the book), and man lahū syibhah kitāb (believer of the pseudo-book). It is interesting noting that Shahrastānī uses term of practice or religious believer (Muslim) and not use term of the doctrine or religion (Islam). He seems to hold anthropological perspective which concerns on phenomenological reality on seeing religion. ${ }^{16}$ In other words, he focuses more on how people know and understand their religion, not religion itself as a structure. For instance, when he explains al-Yahüd (Jews), he starts by defining them as "the people of

\footnotetext{
${ }^{14}$ Philip Johnson, Apologetics, Mission and New Religious Movement: A Holistic Approach (Salt Lake City: ST Academic Press, 2010).

${ }^{15}$ Knitter, Introducing Theologies of Religions, 19-56.

${ }^{16}$ Read James Cox, An Introduction to the Phenomenology of Religion (London: Continuum, 2010), 146-172.
} 
Moses. Their holy book is Torah, the first holy book given by God." ${ }^{17}$ When he describes al-Nasārā (Christian), he also starts by defining the people and not the doctrine or religious values in Christianity. "Christian are the people of Jesus, the son of Maria, the Prophet of God, the logos, committed after Moses, who was mentioned before in the Torah." ${ }^{18}$ In the second volume, Shahrastāni explores what he called ahl al-ahwä wa al-nihal (the people of thoughts and cults). In this volume, like the previous volume, Shahrastānī underlines his account on the people, e.g. al-muta'akhirūn min faläsifah al-Isläm (the latest of Islamic philosophers), 'abadah al-kawākib (the star worshipers), etc.

Although the title of his book is al-Milal wa al-Nihal (Religions and Cults), but Shahrastāni emphasizes on discussing the believer of the faith more than the doctrine itself. It means, again, that how religious believer know and understand their religion-in Shahrastānīs view-is the essential of "the religion" itself. This method remains significant in the whole explanation of Shahrastānī’s book.

More than fifty years before Shahrastānī, 'Abdul Qāhir al-Baghdādī (1037) wrote his book, Kitāb al-Milal wa al-Nihal (The Book of Faiths and Religions). This manuscript has the same tittle with Shahrastānīs book, but it focuses only on Islamic thoughts and cults. In this manuscript, al-Baghdādī explores several sects in Islam, e.g. al-Khawārij, al-Mu'tazilah, al-Murjiah, Najjäriyyah, and al-Jahmiyyah. ${ }^{19}$ Besides this manuscript, al-Baghdādī wrote several books in the same topic, such as Fadā'ih al-Mu'tazilah, Ibtāl al-Qaul bi al-Tawallud, al-İmān wa Usūluhu, Nafy Khalq al-Qur'ān, and al-Farq Baina al-Firaq (The Differences among Different Groups). ${ }^{20}$ In the last book, al-Baghdadi deepens his explanation on distinctive Islamic cults to enrich Muslim's perspective on ideological differences among Muslims.

Within this era, there was another prolific Muslim scholar who wrote in many disciplines of Islamic studies, such as Islamic jurisprudence, Islamic law, poetry, history, ethics, and religious study. Just to mention few of them are al-Ihkām fì Usūl al-Ahkām, al-Muhallā bi al-Ātsār, Tuq al-Hamāmah, alAkhlāq wa al-Siyar, and al-Fasl fì al-Milal wa al-Ahwä'wa al-Nihal. He is Abù Muhammad 'Ali ibn Ahmad ibn Sa'īd ibn Hazm (994-1064), well known as Ibn Hazm al-Zahirī al-Andalūsī. In term of religious study, his book al-Fasl fì alMilal wa al-Ahwä wa al-Nihal has become a main reference for next Muslim scholar who wrote on the same issue. In this book, Ibn Hazm wrote his ideas

\footnotetext{
${ }^{17}$ Al-Shahrastānī, al-Milal wa al-Nih\}al (Beirut: Dar Ibn H\}azm, 2005), 142.

${ }^{18}$ Ibid., 149.

${ }^{19}$ Abū Mans\}ūr 'Abdul Qāhir al-Baghdādī, Kitāb al-Milal wa al-Nih\}al (Beirut: Dar al-Masyriq, 2006).

${ }^{20}$ Al-Baghdādī, Kitab al-Milal wa al-Nih\}al, 40.
} 
on religious study based on socio-political situation at the time. However, he used textual-epistemology to analyze and examine the truth claim of each religion, through criticizing its holy scripture. He comparatively discussed religions (such as Islam, Christianity, and Judaism) referring to its textual scripture as the ultimate reference. This method has been well known as Ibn Hazm's distinctive analytical approach (al-Zahiriyyah/textualism) ${ }^{21}$

In the context of religious studies, some Muslim scholars have also written specific topic concerning specific religion. Al-Bīrūnī (973-1048) wrote his book Mà lil Hind min Maqūlah Maqbūlah fì al-Áql aw Mardhulah (Hinduism: Between Accepted and Rejected Logic), Abū al-Maālī al-Juwainī (1028-1085) wrote a book Shifä̀ al-Ghalìl fì al-Radd 'alā Man Baddala al-Taurāh al-Injīl (Answers for Whom Substituted the Torah with the Bible), al-Imām al-Ghazālī (1058-1111) wrote his book al-Radd al-Jamìl li Ilāhiyyah 'Isā bi Sarīh al-Injīl (Responses on Divining Jesus Based on the Bible), al-Imām ibn Taimiyya (1263-1328) wrote on al-Jawāb al-Sahīh li Man Baddala Dīn al-Masīh (Right Answer for Whom Exchanged Religion of Christ), etc. ${ }^{22}$

From this phenomenon, we understand that many classical Muslim scholars responded religious plurality and cultural differences through making meaningful book discussion and polemics. They have been fighting for and justifying their own religion by explaining what they academically understood and trusted. No matter they opposed each other, religiously and academically, they preferred to reveal their standpoint by giving an academic argumentation. This approach avoids them from taking extreme or radical response toward the opposite other. To know and have comprehensive understanding of other could build inclusive approach on responding conflictual situation. Referring to Jeroen Adam (2010), we can call such approach as a part of "integrative approach": providing many innovative insights toward communal violence occurred. ${ }^{23}$ In other words, academic approach-although it was polemical and apologetic-represents one of constructive factor for accepting and recognizing other.

Following the path of previous Muslim scholars, many scholars in the modern era also wrote books on religious studies to enrich Muslim's understanding in term of their own and other's religion. Muhammad 'Abduh (1849-1905),

${ }^{21}$ Amr Osman, The Zahiri Madhhab: A Textualist Theory of Islamic Law (Boston: Brill, 2014), 77-88.

${ }^{22}$ Read Muh\}ammad 'Abdullah al-Sharqāwī, "Ahammiyyah al-Bah\}th fī Muqāranah al-Adyān" in al-Imām al-Ghazālī, al-Radd al-Jamīl li Ilāhiyyah 'İsā bi S\}arīh al-Injīl (Beirut: Dar al-Jail, 1990), 18-20.

${ }^{23}$ Jeroen Adam, "How Ordinary Folk Become Involved in the Ambonese Conflict: Understanding Private Opportunities During Communal Violence", Bijdragen tot de Taal-, Land-en Volkenkunde, Vol. 166, No. 1 (2010), 25-48. 
known as Muslim philosopher and reformer, wrote his book al-Isläm wa alNasrāniyyah ma'a al-'Ilm wa al-Madaniyyah (Islam and Christianity: Between Science and Civilization). In this book, Muhammad 'Abduh answered some topical issues concerning Islam, Christianity, modernity, philosophy, and civilization. The book is a compilation of 'Abduh's essays published in $\mathrm{Al}$ Manār magazine. He argued that religion, namely Islam, does not urge Muslim society into social failure and political weakening. It was politics and powerbased motivation that interfere with human development. ${ }^{24}$

Strengthening 'Abduh's manuscript on polemical discourse of Islam and Christianity, Sayyid Rashīd Ridā (1865-1935) wrote Shubuhāt al-Nasārā wa Hujaj al-Islām (The Confusions of Christianity and the Arguments of Islam). This book consists of sixteen essays published previously in al-Manār to answer questions and disagreements toward Islam. Rida aims to explain Moses, Jesus, and Muhammad as well as to explore polemics of Islam and Christianity. He also discusses several topics which underlines that Islam is religion of rationality. In line with 'Abduh, he insists that Islamic theology has no relation with social problem of Muslims: it is not about the teachings, but the Muslim's practice. ${ }^{25}$

Muhammad 'Abduh and Rashìd Rida share their concern on responding alghazw al-fikr (intellectual invasion) toward Islam and Muslim society. Through their publication, al-Manār, they endorse logical and rational thought of Islam. This effort intends to create interactional space between Muslim and other believers, in term of debatable issues and theological polemics. Academic discourse does empirically build more understanding than misunderstanding and downgrade cynical attitude among religious followers. Besides physical meeting with other devotees, Muslim needs to conduct intellectual encounter for discussing religious ideas.

Continuing this apologetic approach, Muhammad Abū Zahrah (1898-1974) wrote at least two volumes on religious studies. First volume is about religion of Egypt, Brahmanism, Buddhism, and Confucianism. Interestingly, in this volume Abū Zahrah preferred to use Brahmanism (al-Barahmiyyah) on describing Indian religions than Hinduism (al-Hindūkiyyah). ${ }^{26} \mathrm{He}$ followed Shahrastānī on using the term, although they were living in different era. Second volume is specific about Christianity. In this volume, Abū Zahrah

${ }^{24}$ Muh\}ammad 'Abduh, Al-Islām wa al-Masīhiyyah Baina al-'Ilm wa al-Madaniyyah (Cairo: Dar al-Manar, 1953), 145-150.

${ }^{25}$ Sayyid Rashīd Ridā, Shubuhāt al-Nas\}rāniyyah wa H\}ujaj al-Islām (Cairo: Dar alManar, 1947), iii.

${ }^{26}$ In his book, al-Islām wa al-Adyān, Mus\}tafa $\left.\mathrm{H}\right\}$ ilmī uses both of these terms interchangeably without clear explanation of practical differences between them. See Mus\}tafa $\mathrm{H}\}$ ilmī, al-Islām wa al-Adyān (Beirut: Dar al-Kutub al-'Ilmiyyah, 2004), 40. 
explored history of Christianity, doctrine, and its sects. ${ }^{27} \mathrm{He}$ emphasized that his method in comparative study of religion is to read, observe, and analyze other religion from the holy book and other key-document of each religion. He also persisted that Islam remains rational and logical religion that encourages human for advocating humanity (Sälah al-Insāniyyah)..$^{28}$ This approach illustrates Abū Zahrah's apologetic position on studying religions.

Another prominent Muslim scholar who concerns on comparative study of religions was Ahmad Shalabi (1915-2000). He wrote several books on comparative study of religions, such as Hinduism, Judaism, Christianity, and Islam. ${ }^{29}$ His writing often attacks the essence of other religion as a common form of apologetic approach. He wrote in his introduction, for instance, that Christianity was a simple faith in the era of Christ but Christian believer made it more difficult and complicated. ${ }^{30}$ Shalabi persisted that comparative study of religion is an Islamic invention because, according to him, Islam is the only religion which accepted religious diversity. Religions outside Islam tend to identify other faith and other religious community as "infidel" and "heretical". 31

In 2004, a book written by Mustafā Hilmī was published in Egypt. The book represented compiled lectures of him during his fellowship at the Umm al-Qura University, Saudi Arabia. In this book, Hilmī describes at least six religions: Hinduism, Buddhism, Zoroaster, Judaism, Christianity, and Islam. He emphasized on differentiating Islam as divine-based religion with other religion with human-based affiliation. He referred to traditional discourse on what he called as philosophical approach and religious approach. According to him, Islam did not recognize philosophy as conceived and understood in Greek and the Western world. He developed al-istidlāl al-'aqlì (logical argumentation) which has been practiced by traditional and modern intellectual of Muslim. ${ }^{32}$ Hilmì tends to face Islam with western modernity and attempts to reconstruct romanticism of Islam far from the shadow of western achievement. ${ }^{33}$

${ }^{27}$ Muhammad Abū Zahrah, Muqāranah al-Adyān al-Diyānah al-Qadīmah (Cairo: Dar al-Fikr al-Arabi, 2006), 5. Read also Muh\}ādarāt fī al-Nasrāniyyah (Cairo: Dar al-Fikr al-aArabi, 2006).

${ }^{28}$ Ibid.

${ }^{29} \mathrm{He}$ wrote several volumes on comparative religion, such as al-Yahüdiyyah (Judaism), al-Masīh\}iyyah (Christianity), al-Islām, and Adyān al-Hind al-Kubrä (Religions of India). All volumes are published by Dār al-Nahdah al-Mis\}riyyah.

${ }^{30}$ Ahmad Shalabi, Muqāranah al-Adyān: al-Masīhiyyah (Cairo: Dār al-Nahdah al-Mis\} riyyah, 1993), 21.

${ }^{31}$ Ahmad Shalabi, Muqāranah al-Adyān: al-Yahūdiyyah (Cairo: Dār al-Nahdah al-Mis\} riyyah, 1996), 27.

${ }^{32}$ Mus\}tafa H\}ilmī, al-Islām wa al-Adyān Dirāsah Muqāranah (Cairo: Darul Kutub al-Ilmiyah, 2004), 15.

${ }^{33}$ Mus\}tafa H\}ilmī, al-Islām wa al-Adyān Dirāsah Muqāranah, 16. 
In Indonesia, comparative study of religion could be rooted from Nuruddin ar-Raniri's book, Tibyan fi Ma'rifah al-Adyan (Description on Understanding Religions). He was an Indian-Arab origin who worked as shaikh al-Isläm in the Sultanate of Aceh during 1637-1643. In this book, Raniri in general followed Shahrastānīs outline on elucidating world religion and exploring 72 sects in Islam. Karel Steenbrink persisted that the work of Raniri was exceptional because it was the only book of comparative study in Indonesia written before the 20th century. ${ }^{34}$ Other Indonesian Muslim scholars continued Raniri's work in the $20^{\text {th }}$ century, starting from Mahmud Yunus who wrote his book al-Adyān (Religions), Zainal arifin Abbas who wrote Perkembangan Fikiran terhadap Agama (The Development of Ideas Concerning Religion), Mukti Ali (the first Dean of the faculty of Comparative Religion in Yogyakarta) who wrote many articles relating to religious studies such as Asal-usul Agama (The Origins of Religion) published by Journal Al Djamiah.

This historical lineage on comparative study of religion in Muslim society asserts that to know other religions (or religious others) is not less important than to know our own religion. Muslim scholars tried to bridge our religious knowledge with religious knowledge of other. In this regard, we may mention what Fuad Hassan explained as "togetherness" in his book Kami and Kita: The Basic Modes of Togetherness. ${ }^{35}$ In other words, to involve religious others into our life is to know better and accept them through inclusive approach. We should learn to habituate of being kita more than of being kami as exclusive attitude which tends to exclude opposite community. In kita-world, different community (I and You) can exist and coexist as pronounced subjectivity in one reality. ${ }^{36}$

\section{RECOGNIZING OTHERS}

As a religion, Islam endorses peaceful spirit through its foundation, the Qurān and Hadìth. In Islamic tradition, it is renounced that everyone cannot be religious if he or she still commits violence against religious others. ${ }^{37}$ The prophet Muhammad said, "Spread a peace (al-salām) between you." ${ }^{38}$ In another hadith the prophet insisted that "A Muslim is a person who advances peaceful relation toward other Muslims (and other people), through his

\footnotetext{
${ }^{34}$ Karel Steenbrik, “The Study of Comparative Religion by Indonesian Muslims”, Numen, vol. 37, Fasc. 02, (December 1990), 144.

${ }^{35}$ Fuad Hassan, Kita and Kami: The Basic Modes of Togetherness (Winoka, 2005).

${ }^{36}$ Fuad Hassan, Kita and Kami, 26.

${ }^{37}$ Majdì Riyād, Al-Muqaddas wa Ghairu al-Muqaddas wa Qadāyā al-Fikr al-Islāmī (Cairo: Akhbār Ta’līm, 2004), 19.

${ }^{38} \mathrm{HR}$. Muslim. (Translation is mine)
} 
mouth (statement) and hand (action)." 39 The hadith is adequately ample to affirm that Islam, in its basic principle, condemns violence, extremism, and radicalism. Islam supposes to challenge every single contradictory position through a peaceful dialog and a better discourse. ${ }^{40}$

To reach the "acceptance level" for recognizing other existence, Muslims need to have thorough understanding about their religion as well as religion of others. Elucidating some Muslim countries such as Indonesia and Senegal, Alfred Stepan introduces what he called as "co-celebratory" to articulate accommodative relation between state and religion. In this context, "religion is publicly acknowledged by the democratic state as being an important part of the private and public life of all citizens." 41 The accommodative action requires recognition, and recognition entails an apt awareness of other. Referring to Taylor, he highlights "mutual recognition" to achieve harmonious integration. ${ }^{42}$

The idea is essential to reinvent academic approach toward religious diversity as an empirical evidence of multiculturalism. Having many religious sects and movements, Indonesian people are used to experience not only their own religious ceremony but also religious festival of other community. On the one hand, this phenomenon can reproduce social awareness as well as reveal social pathology and detestation, on the other. Comprehensive understanding and inclusive approach may bridge ideological or theological disparities between two or more faiths, to attach them within philosophical boundary of toleration.

Looking at the previous case of regret feeling of the ISIS followers, we may ponder two different realities: experienced bad life in the past and imagined good life in the present. People are moving away from wicked reality to achieve better and more respectable actuality. To some extents, such condition is conducted by changing knowledge and transformed understanding about the real life, including how they perceive religious life. Radicalism, as a part of current religious phenomenon, cannot be separated from this touching influence. Indeed, everyone must have right understanding about something (idea, action, movement, state, religion, etc.) in which he or she involves.

Cultivating his idea of communicative action, Habermas argued that reason is essential domain where someone's understands and reflection are embedded

${ }^{39}$ HR. Bukhari Muslim. (Translation is mine).

${ }^{40}$ See QS. Al-Nah\}l: 125.

${ }^{41}$ Alfred C Stepan, "Moslem and Toleration: Unexamined Contributions to the Multiple Secularism in Modern Democracies" in Alfred Stepan and Charles Taylor, Boundaries of Toleration (New York: Colombia University Press, 2014), 275.

${ }^{42}$ Eduardo Mendieta (et.al), The Power of Religion in the Public Sphere (New York: Colombia University Press, 2011), 129; Charles Taylor, “The Politics of Recognition” in Amy Gutmann (ed.), Multiculturalism: Examining the Politics of Recognition (Princeton: Princeton University Press, 1994), 25-73. 
and embodied within. ${ }^{43}$ In this regard, interaction could represent equal conversation between one group to another, one community to another, and one person to another. It indicates that understanding other could enrich social encounter and, in some degree, reduce radical response toward other. Here, notion of academic approach appears as a tool for building peaceful network and fruitful communication.

When Muslim scholars (both in traditional and modern era) wrote the books on comparative study of religion, they aim to extend Muslim understanding concerning other religions and sects. They realize that understanding religion, namely Islam, becomes a necessity to strengthen religiosity and conviction of the believer. ${ }^{44}$ Though this approach tracks on apologetic and polemical approach on describing or attacking other religions, legacy of comparative religion still remains definite and relevant to reinvent academic discourse. To focus more on intellectual assessment is to elude, for some reasons, radical action. Closing eyes from other religious insight tends to claim for having and acting based on "the mind of God". Juergensmeyer argues that "religious ideas and the sense of religious community have been endemic to the cultures or violence from which terrorism has sprung." ${ }^{45} \mathrm{He}$ warns us to look carefully at general belief that continues reproducing what it is called "cosmic war". ${ }^{46}$ Considering that our belief is the only truth and imagining others as always wrong may create oblivious seed of demonization. This kind of excessive piety will easily ignore religious others.

In his book, Al-Islām baina al-Ghuluw wa al-Jafä' wa al-Ifra' wa at-Tafrit, 'Abdullah ibn Jibrīn describes three different religious individual or group based on their thought and practice ${ }^{47}$ First, it is individuals with neglecting attitude toward their religiosity who easily ignore and disregard religious teaching. These individuals perceive religious doctrine as "profane" object in which people can rationally play with. In Islamic tradition, this standpoint is called tafrit. Second, it is individuals with excessive obedience toward religious order. They attempt to perform not only an obligatory order of religion but also another voluntary practice of it: without scrutinizing and examining validity of the order. It is called ifra'. Both of tafrit and ifra' are pleonastic. In

${ }^{43}$ Jurgen Habermas, The Theory of Communicative Action (Boston: Beacon Press, 1984), 1-42.

${ }^{44}$ Muhłammad 'Izzat T\}ah\}t\}āwī, Al-Mīzān fì Muqāranah al-Adyān: Haqāiq wa Wathāiq (Damascus: Dar al-Qalam, 2002), 10.

${ }^{45}$ Mark Juergensmeyer, Terror in the Mind of God (Barkeley, University of California Press, 200), 216.

${ }^{46}$ Ibid., 145.

${ }^{47}$ 'Abdullah ibn 'Abdurrah\}mān Jibrīn, Al-Islām baina al-Ghuluw wa al-Jafă' wa al-Ifrat\} wa al-Tafrit\} (kitab, Inc., 2015); Mālik Mus\}tafā 'Amilī, Maqās\}id al-Syar'i baina al-Ifrat\} wa at-Tafrit\} (Beirut: Dar al-Hādī, 2007). 
term of intra and inter-religious interaction, excessive religiosity could neglect religiosity of others. Third, it is people with moderate religious practice. They perform religious practice as it is ordered without ignoring or rejecting different religions and sects. Referring to Paul Knitter, this approach can be classified as "the acceptance model" where believer respect and recognize religious belief of others as it is. ${ }^{48}$

Using practical term of medical science, the second approach (ifra) may be named as "religious obesity". In medical science, obesity can be identified as having high percentage of body fat. It distinguishes than overweight which means having more body weight than is considered normal. ${ }^{49}$ The first may increase risk of body health, while the second may only overlook ideal weight of body. In this regard, radicalism could be classified as having high percentage of excessive religiosity that may defeat religiosity of others. Furthermore, comprehensive knowledge about other religions must be outspreaded.

\section{CONCLUSION}

In some cases, radicalism is a product of misunderstanding and idiocy. Literary activism could be an academic preference to avoid it. When Muslim scholars, both in traditional and modern period, wrote books on comparative religion, they experienced by themselves to accommodate different faiths through academic discourse on the one hand, whereas their books enlightened readers to appreciate the existence of other different religions on the other. Understanding will lead someone to recognition as a basic attitude on building inter-religious harmony. It is worth noting that our response to certain contradictory condition depends on our understanding on it. The more we understand, the more we appreciate. In this regard, literacy is needed to nurture academic approach toward fundamental and radical movement.

\section{BIBLIOGRAPHY}

'Abduh, M. (1953). Al-Islām wa al-Masīhiyyah Baina al-'Ilm wa al-Madaniyyah. Cairo: Dar al-Manār.

'Amilī, M. M. (2007). Maqāsid al-Syar'i baina al-Ifrat wa at-Tafrit. Beirut: Dar al-Hādī.

Adam, J. (2010). How Ordinary Folk Become Involved in the Ambonese Conflict: Understanding Private Opportunities During Communal Vio-

\footnotetext{
${ }^{48}$ Paul Knitter, Introducing Theologies of Religions (New York: Orbis Books, 2002).

${ }^{49}$ Judith S Stern and Alexandra Kazaks, Obesity: A Reference Handbook (Santa Barbara: ABC-CLIO, 2009), 4.
} 
lence. Bijdragen tot de Taal-, Land-en Volkenkunde, Vol. 166, No. 1.

Al-Ámirī, A. 'A. K. G. (1997). Al-Jadd al-Hasis fì Bayāni mā Laisa bi Hadìth. Beirut: Dar Ibn Hazm.

Al-Baghdādī, A. M. 'A. Q. (2006). Kitāb al-Milal wa al-Nihal. Beirut: Dar al-Masyriq.

Al-Ghazālì. (1990). al-Radd al-Jamìl li Ilāhiyyah 'İsā bi Sarīh al-Injīl. Beirut: Dar al-Jail.

Al-Shahrastānī. (2005). Al-Milal wa al-Nihal. Beirut: Dar Ibn Hazm.

Apostolov, M. (2004). The Christian Muslim Frontier: A Zone of Contact, Conflict or Cooperation. New York: Routledge.

Ayoub, M. M. (2001). Mengurai Konflik Muslim-Kristen dalam Perspektif Islam. Yogyakarta: Fajar Pustaka Baru.

Cox, J. (2010). An Introduction to the Phenomenology of Religion. London: Continuum.

Farrukh, O. (1982). Al-Tabshīr wa al-Istìmār fì al-Bilād al-Áarabiyyah. Beirut.

Gutmann, A. (ed.). 1994). Multiculturalism: Examining the Politics of Recognition. Princeton: Princeton University Press.

Hilmī, M. (2004). Al-Islām wa al-Adyān. Beirut: Dar al-Kutub al-'Ilmiyyah.

Habermas, J. (1984). The Theory of Communicative Action. Boston: Beacon Press.

Hassan, F. (2005). Kita and Kami: The Basic Modes of Togetherness. Jakarta: Winoka.

Jibrīn, 'A. 'A. (2015). Al-Islām baina al-Ghuluw wa al-Jafä' wa al-Ifrat wa alTafrit. KSA: kitab, Inc.

Johnson, P. (2010). Apologetics, Mission and New Religious Movement: A Holistic Approach. Salt Lake City: ST Academic Press.

Juergensmeyer, M. (2009). Terror in the Mind of God. Barkeley: University of California Press.

Knitter, P. (2002). Introducing Theologies of Religions. New York: Orbis Books.

Mendieta, E. (et.al). (2011). The Power of Religion in the Public Sphere. New York: Colombia University Press.

Osman, A. (2014). The Zahiri Madhhab: A Textualist Theory of Islamic Law. Boston: Brill. 
Ridā, S. R. (1947). Shubuhāt al-Nasrāniyyah wa Hujaj al-Islām. Cairo: Dar al-Manār.

Riyād, M. (2004). Al-Muqaddas wa Ghairu al-Muqaddas wa Qadāyā al-Fikr al-Islāmī. Cairo: Akhbār Ta’līm.

Said, E. (1979). Orientalism. New York: Vintage Book.

Shalabi, A. (1993, 1996). Muqāranah al-Adyān: al-Yahūdiyyah. Cairo: Dār al-Nahdah al-Misriyyah.

Steenbrik, K. (1990). The Study of Comparative Religion by Indonesian Muslims. Numen, vol. 37, Fasc. 02.

Stepan, A \& Charles, T. (2014). Boundaries of Toleration. New York: Colombia University Press.

Stern, J. S. \& Alexandra, K. (2009). Obesity: A Reference Handbook. Santa Barbara: ABC-CLIO.

Swidler, L. (1984). The Dialogue decalogue: Ground Roles for Interreligious Dialogue. Journal of Inter Religious. 5.

Tahtāwī, M. 'I. (2002). Al-Mīzān fī Muqāranah al-Adyān: Haqāiq wa Wathāiq. Damascus: Dar al-Qalam.

Waardenburg, J. (2017). Classical Theories of the Study of Religion: Aims, Methods, and Theories of Research. Berlin: de Gruyter.

Zahrah, M. A. (2006). Muhādarāt fì al-Nasrāniyyah. Cairo: Dar al-Fikr al'Arabī.

Zahrah, M. A. (2006). Muqāranah al-Adyān al-Diyānah al-Qadìmah. Cairo: Dar al-Fikr al-'Arabi. 
